Krisztina Sárdi

UDK 821.111(73).09:008(443.611)"'192-"

Pázmány Péter Catholic University

Budapest, Hungary

sardi.kriszta@gmail.com
DOI: 10.4312/vestnik.7.17-26

\title{
“THERE'S NEVER ANY ENDING TO PARIS" CREATING A LITERARY MYTH: GEOCRITICAL ASPECTS OF THE WORKS OF THE LOST GENERATION
}

The primary objective of this essay is to show the different images of Paris described by the authors of the Lost Generation using a geocritical approach, in order to present how their representations of the French capital had contributed to the construction of today's mythical/stereotypical perception of Paris. I also intend to deconstruct some clichés about the French capital, generally regarded as the city of arts, love and lights. Consequently, I am aiming to explain what it meant to be lost in Paris or to be lost in the twenties, why the American and British authors and artists of the era wished to rebuild their lives on the old continent, how Paris became their cultural safe haven and what remained of its mythical picture.

Geocritical analysis can also shed light on the different literary perceptions of Paris in the twenties in literary works, written by Francis Scott Fitzgerald (Babylon Revisited, 1935), Ernest Hemingway (A Moveable Feast, 1964) and Gertrude Stein (Autobiography of Alice B. Toklas, 1933 and Paris, France, 1940). To appropriately address the latter topic, the meaning of the denomination "Lost Generation" needs to be clarified and some examples of the blossoming cultural life on the Left Bank of the Seine in the "roaring" twenties need to be analysed. Through the texts of Sylvia Beach (Shakespeare \& Company, 1959) and Hugh Ford (Published in Paris, 1975) one can certainly catch a glimpse of the literary scene of the era. Everything the expatriates established or achieved - from the little bookshops to the small presses run by them, over the readings and reviews (like Ford Madox Ford's transatlantic review) - contributed to the literary construction of the French capital. And finally, the aftermath of this phenomenon triggered Paris' mythical status in literature.

\section{WHAT IS GEOCRITICISM?}

Hemingway once wrote to a friend: "If you are lucky enough to have lived in Paris as a young man, then wherever you go for the rest of your life, it stays with you, for Paris is a 
moveable feast" (Hemingway 2009: XII). It can be argued that this phrase represents in the best possible way the secret, the attractiveness of Paris for hundreds and thousands of artists and tourists, then and now as well. Provided that most of his contemporaries felt the same way, one has to question what specifically made Hemingway write this description of Paris, the city of arts, lights and love.

Solely based on the principle of the spatial turn, the geocritical theory and analysis of Bertrand Westphal may help to shed some light on the Parisian phenomenon: to discover what lies behind the contemporary stereotypical image of Paris and how the literary myth of Paris was born. Geocriticism (la géocritique) is an interdisciplinary method of literary analysis that incorporates the study of geographic space.

To give a brief overview of spatiality studies, one should specify that space has had a timely re-emergence in literary and cultural studies in the recent years: in the second half of the twentieth century, the discourse of postmodernism focused on the importance of space, geography and cartography. Michel Foucault observed in Of Other Spaces (Des Espaces Autres, 1984) that "the present epoch will perhaps be above all the epoch of space" (1984: 46 ), in contrast to the former reign of time- and text-centered researches. Critics, such as Mikhail Bakhtin, Homi K. Bhabha, Gilles Deleuze and Félix Guattari or Henri Lefebvre increasingly focused attention on the relationships between space, place, culture and literature. This growing body of critical works on the interdisciplinary field of spatiality studies was defined in literary and cultural studies as the spatial-turn by Edward Soja in Thirdspace (1996). Soja reformulated Lefebvre's spatial concept introducing a theory of spaces that are both real and imagined. Bertrand Westphal's geocriticism can be considered as a revised and improved version of Soja's theories.

Some of the first expressly geocritical writings emerged from symposium organized by Westphal around 2005 at the University of Limoges, in France. Westphal's fundamental essay, Pour une approche géocritique des textes constitutes a manifesto for geocriticism in which he constructs a theoretical framework for the discipline. As Westphal explains, "the main aim of geocriticism is to examine the interactions between literature and human spaces". He elaborated on the theory in greater detail in La Géocritique. Réel, fiction, espace (2007), translated to English by Robert Tally in 2011 (Geocriticism: Real and Fictional Spaces). By questioning the relations between the nature of a real-world space and its actual condition, it also assumes a literary referentiality between world and text, or, in other words, between the referent and its representation(s). Moreover, geocriticism can also study the effects of literary representations of a given space. Consequently, the geocritical approach enables a study of places described in the works of various authors, making geocriticism multifocal, examining a variety of topics at once.

In addition, geocriticism is based on three theoretical concepts: spatio-temporality, transgressivity and referentiality. The concept of spatio-temporality draws the critic's

1 Translation from French by the author 
attention to focus on the link which makes of space and time a continuum. On transgressivity, Westphal attempts to understand that the real and fictional spaces that we inhabit or cross through are in a constant back-and-forth movement - which leads us to the referentiality operating between fiction/literature and the real world. For that reason, our understanding of a particular place is determined by our experiences of it, but also by our reading about others' experiences, by our point of view, including our biases and wishful thinking.

When it comes to the practical side of the method, as a result of the preceding ideas, geocritical analysis relies on four principles: multifocalization, polysensoriality, stratigraphic perspective and intertextuality. To overcome our stereotypical images of Paris, one has to consult as many texts as possible, written from different perspectives - the top priority is to develop the widest array of points of view: for example, of the flâneur, the traveller or the autochthon. Among the scrutinised texts, the ones by Fitzgerald present the point of view of the flâneur, those of Hemingway's reflect the perspective of the traveller because they highlight the exotic and wonderful sides of Paris - only Stein's position is close to what we could call an autochthonous description of the city.

\section{POLYSENSORIALITY}

The principle of polysensoriality recommends that a geocritical analysis of a given space must engage all five senses reminding the geocritic to examine the auditory, visual, olfactory, gustatory and tactile dimensions of place. In other words, the different imaginary faces of Paris should be painted by all five senses: the hearing, the sight, the smell, the taste and even the touch has to play a role in the perception of the real space.

Ernest Hemingway's posthumously published novel, A Moveable Feast (1964) demonstrates the best way this technique of interpretation: "The Café des Amateurs was the cesspool of the rue Mouffetard, that wonderful narrow crowded market street which led into the Place Contrescarpe. The squat toilets of the old apartment houses, [...] were emptied by pumping into horse-drawn tank wagons at night. In the summer time, with all windows open, we would hear the pumping and the odour was very strong. The tank wagons were painted brown and saffron colour and in the moonlight when they worked the rue Cardinal Lemoine their wheeled, horse-drawn cylinders looked like Braque paintings" (2009: 15-16). As the preceding extract shows, the author was amazed by everything the city had to give him, and he applies a wide array of colours and odours to describe the city's visual dimensions, besides writing about the shape of the Parisian streets to evoke the joyful atmosphere of the place.

On that account, Hemingway's representation of the city undoubtedly contributed to today's preconception that sees life in Paris as a never-ending whirl. Moreover, he drew numerous analogies between art and everyday life (saying for example that the Parisian tank wagons have the appearance of cubist pictures) which shows us where the cliché of Paris being the city of arts possibly originated from. 


\section{STRATIGRAPHIC DEPTH}

The stratigraphic aspect of geocriticism stresses the idea that the description of a given place consists of an accumulation of past moments, so the analysis has to study the selected place over time, at different moments of its history to reveal what lies behind the surface of the text.

Unlike Hemingway, Francis Scott Fitzgerald paints a rather dark image of Paris: as he reinterprets his own memories of the roaring twenties, the Paris of Babylon Revisited (a retrospective short story written in the thirties) turns into a place full of sorrow, pain and regret. Fitzgerald reflects certain disillusionment: "As they rolled on to the Left Bank and he [Charlie, the protagonist of the story] felt its sudden provincialism, he thought, 'I spoiled this city for myself. I didn't realize it, but the days came along one after another, and then two years were gone, and everything was gone, and I was gone'. [...] He wanted to jump back a whole generation and trust in character again as the eternally valuable element. Everything else wore out." (2006: 219-220). Apparently, seeing it from Fitzgerald's position, Paris had lost its magic; it is no more the land of dreams as it was before. Compared to Hemingway's wonderful image of the city in the twenties, the Paris of Fitzgerald's memories is old and dusty; what is most striking in the latter context is the use of the word "provincialism" by which he attempts to underline that Paris became old-fashioned.

On the other hand, Gertrude Stein, in her autobiographical novel, Paris, France (published at the time of the Occupation in 1940), also gives us a few glimpses of a bygone Paris. She lived in the French capital for at least half a century, therefore her description could as well demonstrate that stratigraphic aspect of the geocritical analysis. "The quays in Paris have never changed, that is to say they look different but the life that goes on there is always the same" (1970: 102) - she says highlighting the never-ending, eternally returning side of the city (one of the main factors on which our theory about Paris being a literary myth can be based). Her standpoint is similar to Hemingway's as she mentions the smell of the city: "It came up first in such different books, Jules Verne and Alfred de Vigny and it came up in my mother's clothes and the gloves and the sealskin caps and muffs and the boxes they came in. There was the smell of Paris in that" (1970: 1-3). Although, explaining it by her childhood's memories (by books she loved and by her mother's clothes) suggests that it feels like being at home rather than discovering a new and exciting city for the first time (which is the case for Hemingway).

Even if their pictures of Paris are different, Fitzgerald and Stein describe the city as time goes by, reinterpreting their memories, their old reflections, thus showing that Paris has many different faces. When representing past moments, both of them are pointing out how time can affect our perceptions of a given space/place. 


\section{REFERENTIALITY AND INTERTEXTUALITY}

Westphal underlines in La Géocritique that our perception of a certain place depends on different levels of interpretation (2007: 247), hence the importance of examining the concept of referentiality and intertextuality. He reveals that among literary spaces there are the ones being totally and undoubtedly fictional, and there are others which evoke a sense of reality. So, the critic should discover the interactions, the constant back-and-forth movement between the real place and its literary/imaginary representations. In other words, the question is to what extent the author writes the truth and whether the literary images of the real place are merely fictional and subjective, transformed and reinterpreted by our memory or there is some objective reality behind the perceptions.

For example, Hemingway attempts to confuse the reader about the authenticity of $A$ Moveable Feast: "this book is fiction but there is always a chance that such a work of fiction may throw some light on what has been written as fact" (2009: 229-230). It sounds like a disclaimer which invites the reader to discover the truth if he/she wants to. Eventually, it is commonly known that A Moveable Feast is a collection of notes of his first impressions on Paris which he had written in the twenties, but they were lost and not found until the late-1950s. Therefore, one should presume that the city described in them is not purely fictional: and if what Hemingway wrote is - at least - partly true, then the Paris of the roaring twenties was really like an endless feast, a festival of the intellectuals (another factor to prove our theory that Paris is a literary myth).

Last but not least, the principle of intertextuality in our geocritical approach refers to the preconception which lies behind one's perception of a place. Westphal specifies that this preconception assembles everything we have ever heard, seen, read about the given place, along with a vision formed by our memories and imagination (2007: 247). Consequently, there are always several layers of interpretation behind our writers' pictures of Paris. For instance, Gertrude Stein's perception of Paris is soundly based on the history of her salon and its guests, portrayed in the Autobiography of Alice B. Toklas.

Miss Stein's salon was the "must-see" place of the twenties: in the Autobiography, pretending to be her companion, Alice Toklas, she shows us the intellectual crowd gathered at her apartment at the rue de Fleurus. "They were always there, all sizes and shapes, all degrees of wealth and poverty, some very charming, some simply rough and every now and then a very beautiful young peasant" (1946: 12-13) from Picasso, Matisse and Jean Cocteau to James Joyce, over Man Ray, Ezra Pound and Ford Madox Ford. Even Béla Czóbel, a young Hungarian painter, member of the "Eight" movement about whom she writes: "in the same room as the Matisse, a little covered by a partition, was a hungarian version of the same picture by one Czobel whom I remembered to have seen at the rue de Fleurus" (1946: 17).

For Gertrude Stein, Paris could be only described and remembered by the arts, by her favourite artists and pieces. That is where the Paris is the city of the arts-cliché is supposedly originated from. Furthermore, in the previously mentioned Paris, France she writes: "France was the proper background for the art and literature of the twentieth century" 
(1970: 22) and "France meant Paris" (1970: 110). So, in the twenties, Paris became the centre of the world for Gertrude Stein and for her many contemporaries.

\section{LOST GENERATION}

In the twenties, Paris was considered the artistic centre of the world, the core of the cultural aftermath of the Great War that genuinely attracted young authors always in need of a new inspirational source. They were really enthusiastic about Paris (even Fitzgerald, despite of his depression, lately expressed in his works) which was partly due to their expatriate status. This exceptional literary context is scrutinised in Sylvia Beach's novel about her bookshop, Shakespeare \& Company which also contributed to the literary and mythical construction of the French capital.

Sylvia Beach, one of the Parisian scene's literary hostesses, made literary history when, in 1922, she published James Joyce's Ulysses - then banned in every English-speaking country in the world, mostly because of its obscenity. Not only Joyce, but most of the writers who were to make the twenties famous were then converging in Paris to live and work. They were all customers at Shakespeare \& Company, and the little bookshop at 12, rue de l'Odéon became the heart of one of the most significant literary movements of the $20^{\text {th }}$ century, the Lost Generation.

In fact, it was Gertrude Stein who invented the expression in conversation with Ernest Hemingway: Stein heard the phrase from a garage owner who serviced her car. When a young mechanic failed to repair the car quickly enough, the garage owner shouted at the boy, "You are all a génération perdue." Stein added: "That is what you are. That's what you all are ... all of you young people who served in the war. You are a lost generation" (2009: 61).

However, it was undoubtedly Hemingway's use of the denomination as the epigraph to The Sun Also Rises (Scribner, 1926), his first novel of wild years spent in Paris and Spain that popularised it. The phrase - and Hemingway's book - depicted this generation as characterised by doomed youth, hedonism, uncompromising creativity, and wounded - literally and metaphorically - by the experience of war. Within that latter context, it is absolutely clear that lost means not vanished but disoriented, wandering, directionless - a recognition that there was great confusion and aimlessness among the survivors in the early post-war years: after the Great War they could not manage to find their place at home, so they moved along. They were lost back at home, they dreamt about finding peace, their path, their mission - one would say - on the "old" continent. As Sylvia Beach explains: "I was too far from my country to follow closely the struggles of the writers there to express themselves, and I didn't foresee, when I opened my bookshop in 1919, that it was going to profit these suppressions across the sea. I think it was partly to these suppressions, and the atmosphere they created, that I owed many of my customers - all those pilgrims of the twenties who crossed the ocean and settled in Paris and colonized the Left Bank of the Seine" (1959: 23). 
They wished to rebuild their lives in a city where the values and virtues they had respected were still valid, not old-fashioned. But obviously there were other reasons of their refuge: "every boat from the other shore brought more customers for Shakespeare \& Company. Of course, prohibition and suppressions were not entirely to blame for the flight of these wild birds from America. The presence in Paris of Joyce and Pound and Picasso and Stravinsky and Everybody - not quite, since T.S. Eliot was in London - had a great deal to do with it" (Beach 1959: 24). In other words, they found in Paris what they had been searching for in vain at home: an inspirational atmosphere (like Fitzgerald who finished his most well-known novel, The Great Gatsby in Paris) or a proper voice (such as Hemingway who slightly shifted from journalism to creative writing while living in the city).

\section{THE LEFT BANK}

What is most striking is the astonishing range, depth, and influence of work produced by this community of American (and British) expatriates in Paris. As Janet Flanner states in her foreword to Hugh Ford's monography (on the history of publishing in the twenties), Published in Paris (1975): "by a coincidence in expatriation, a half-dozen of what turned out to be indubitably the most talented young American writers - Hemingway, Dos Passos, and Fitzgerald were the leaders - were all collected on the Paris Left Bank. Their talent was like a form of colonial energy that had come back to Europe" (1975: XIII).

This outburst of creativity was supported by an explosion of small-scale entrepreneurialism in the creative arts. Much of the literature produced by the American Modernists was published by small presses also run by expatriates, including the previously mentioned Shakespeare \& Company or Robert McAlmon's Contact Editions. Similarly, the Black Sun Press was owned by the Crosby-family and even Gertrude Stein and Alice Toklas had their own publishing company named Plain Editions. All these presses were small, just as William "Bill” Bird's Three Mountains Press where Hemingway worked as well. "He had heard from a fellow-writer of a bargain hand press that was available, and installed it in a tiny office on the Ile Saint Louis. He was engaged in printing a book when I went to see him one day" - tells Sylvia Beach - "he had to come out onto the sidewalk to see me because, as he explained, in his 'office' there was room only for the hand press and the printer-editor" (1959: 130). This special cultural and literary climate had a considerable effect on our authors' images of Paris, and it contributed to the mythical status of Paris in literature. That is mainly why Hemingway called it a moveable feast.

Nevertheless, as all good things come to an end, the growing shadow of the Second World War started to change the life on the Left Bank. "By the thirties, the Left Bank had changed." - Miss Beach writes. "The so-called 'lost generation' - I can't think of a generation less deserving of this name - had grown up and become famous. Many of my friends had gone home. I missed them, and I missed the fun of discovery and the little reviews and the little publishing houses. It had been pleasanter emerging from a war than going toward another one, and of course there was the depression" (1959: 206). 
Sylvia Beach's bookshop was now famous, always crowded with new and old customers, and consequently, it was referred to more and more in the newspapers and magazines. American Express tourists could observe the place as they passed in buses that stopped in front of No. 12 for a couple of seconds. Hemingway's first novel, The Sun Also Rises had been published as well, and even if they returned to the United States, they did not stop writing and thinking about Paris.

This is the moment when the story of the Lost Generation becomes the 'urban legend', and the legend soon starts to change into a myth. Paris as a safe haven for writers is a recurring theme in literature, interpreted by many authors (not only Americans) over decades from Henry Miller to Nancy Houston, through Jack Kerouac, Julio Cortázar and Gilles Leroy. It was even transferred to the cinema (Midnight in Paris, 2011): Woody Allen's presentation of the roaring and magical twenties certainly reinforced the mythical status of the city.

\section{CONCLUSION}

After the Great War, the French capital became a safe haven for the expatriates - not only for the Americans and the Brits, but for the Hungarians and for many other artists as well. In Paris, especially the Americans together with the other English- and French-speaking authors, painters and musicians, formed a sort of colony - and that is the time they created a new literary myth of Paris. By their perceptions of the city - written in novels, magazines and autobiographies or maybe painted in colour - they launched the image of a never-ending Paris, seen as the cultural capital of the world.

As the geocritical analysis revealed, these authors portrayed a joyous city which is always alive, crowded and noisy, "exciting and peaceful" (Stein 1970: 1) at the same time. Nevertheless, there was a certain dark side of Paris as well. Fitzgerald emphasizes this disillusionment in Babylon Revisited: "He [Charlie, the protagonist] was not really disappointed to find Paris was so empty. But the stillness in the Ritz bar was strange and portentous" (2006: 219). Therefore, one could possibly demolish the stereotype of an always scintillating city, while bearing in mind that even this contrast may have contributed to the literary construction of a mythical Paris.

The authors of the Lost Generation never ceased to dream about this wonderful shelter for artists. In Ernest Hemingway's words:

"There is never any ending to Paris and the memory of each person who has lived in it differs from that of any other. We always returned to it no matter who we were or how it was changed nor with what difficulties nor what ease it could be reached. Paris was always worth it and you received return for whatever you brought to it" (2009: 236). 


\section{BIBLIOGRAPHY}

Barthes, Roland/Richard Howard (trans.) (2013) Mythologies: The Complete Edition. New York: Hill and Wang.

BeACH, Sylvia (1959) Shakespeare \& Company: the story of American bookshop in Paris. New York: Harcourt-Brace.

BRUnel, Pierre (1988) Dictionnaire des mythes littéraires. Paris: Le Rocher.

CARPEnTER, Humphrey (2009) Geniuses Together: American Writers in Paris in the 1920s. London: Faber \& Faber.

Eliade, Mircea (1963) Myth and Reality. New York: Harper \&Row.

Fitzgerald, Francis Scott (2006) Babylon Revisited. The Diamond as Big as the Ritz \& Other stories. Ware: Wordsworth Classics, 217-236.

Ford, Hugh (1975) Published in Paris - American and British Writers, Printers, and Publishers in Paris, 1920-1939. London: Garnstone Press.

Foucault, Michel (1984) Of Other Spaces, Heterotopias. Architecture, Mouvement, Continuité 5, 46-49.

Hemingway, Ernest (2009) A Moveable Feast - The Restored Edition. New York: Scribner. LONGSTREET, Stephen (1972) We all went to Paris - Americans in the city of light: 17761971. New York: Macmillan.

SojA, Edward W. (1996) Thirdspace: Journeys to Los Angeles and Other Real-and-Imagined Places. Oxford: Blackwell.

Stein, Gertrude (1946) Autobiography of Alice B. Toklas. C. van Vechten (ed.) Selected Writings of Gertrude Stein. New York: Random House, 1-237.

Stein, Gertrude (1970) Paris, France. New York: Liveright.

WestPhal, Bertrand (2007) La Géocritique. Réel, fiction, espace. Paris: Minuit.

WestPHAL, Bertrand/Robert TAlLy (trans.) (2011) Geocriticism: Real and Fictional Spaces, New York: Macmillan.

Westphal, Bertrand (2005) Pour une approche géocritique des textes. Bibliothèque Comparatiste, SFLGC.

Vox Poetica. November 22, 2015. http://www.vox-poetica.org/sflgc/biblio/gcr.html.

\section{POVZETEK}

\section{"Parizu ni konca"}

\section{Ustvarjanje literarnega mita: geokritični vidiki v delih Izgubljene generacije}

Ta esej predstavlja in analizira podobe oziroma reprezentacije Pariza v različnih delih, ki so jih napisali Ernest Hemingway, Francis Scott Fitzgerald in Gertrude Stein. Teoretičen okvir eseja je geokritika, s pomočjo katere skuša avtorica ugotoviti, kakšen je doprinos teh del k literarni zgradbi francoske prestolnice. Drug namen pa je tudi pokazati rojstvo pariškega literarnega mita. 
Po kratkem pregledu prostorske analize, avtorica podrobno razloži geokritično metodo, in sicer z analizo določenih literarnih izvlečkov, ki pričajo o Parizu iz 20-ih. Izvlečki so iz del Francisa Scotta Fitzgeralda (Babylon Revisited), Ernesta Hemingwayja (Pariz, premični praznik) in Gertrude Stein (Toklas Alice B., Pariz, Francija). Ta pristop lahko pomaga osvetliti razloge, zaradi katerih so ti zdomci (ameriški in britanski pisatelji, umetniki) sploh prišli v Pariz in kaj jih je v njem tako privlačilo. Avtorica nadalje razloži, da so bili umetniki Izgubljene generacije po vojni brez orientacije in ciljev, zaradi česar so se napotili v Pariz, da bi tam našli »stare« vrednote in si na novo postavili življenja.

Ti avtorji so v Parizu našli novo vzdušje, ki jih je navdihovalo, poleg tega pa so našli tudi nove prijatelje in nove cilje. Sprožili so zanimive založniške iniciative, bili so v iskanju svojih lastnih literarnih glasov. Medtem pa so, z zastopanjem vedno razburljivega in natrpanega pariškega življenja, ustvarili literarni mit Pariza, ki to mesto obravnava kot varno zatočišče za umetnike in pisatelje - Pariz je kot neutruden "premični praznik".

Ključne besede: Pariz, Hemingway, Fitzgerald, Stein, geokritika, pariški mit, prostorska analiza, Izgubljena generacija, vojna, iskanje, premični praznik

\section{ABSTRACT}

\section{"There's never any ending to Paris" \\ Creating a Literary Myth: Geocritical Aspects of the Works of the Lost Generation}

This essay proposes to present and analyse the pictures or representations of Paris in Ernest Hemingway's, Francis Scott Fitzgerald's and Gertrude Stein's different works. The theoretical framework of the piece is geocriticism by which the author attempts to discover how these works contributed to the literary construction of the French capital. The other objective of the essay is however to show the birth of a Parisian literary myth.

After giving a brief overview of recent spatiality studies, the paper explains in-depth the geocritical method by the analysis of certain extracts of the different literary perceptions of Paris in the twenties, written by Francis Scott Fitzgerald (Babylon Revisited), Ernest Hemingway (A Moveable Feast) and Gertrude Stein (Autobiography of Alice B. Toklas, Paris, France). The latter approach can help to shed some light on the reasons why these expatriates (American and British writers, artists) came to Paris in the first place and what attracted them so much. Later on, the paper explains that the artists of the Lost Generation were disoriented and aimless after the war, so they headed to Paris to find some 'old' values and rebuild their lifes.

These authors found there a new and very inspirational atmosphere, new friends, new goals, they started interesting publishing initiatives and searched for their proper literary voices. In the meantime, by representing the always exciting and crowded Parisian life, they created a literary myth of Paris which considers the city as safe haven for artists and writers - saying that Paris is a never resting "moveable feast".

Key words: Paris, Hemingway, Fitzgerald, Stein, geocriticism, Parisian myth, spatiality studies, Lost Generation, war, finding, moveable feast 